\title{
5. Re-Reading the Impact of the "Cultural Cold War" on Music History: Cowell, Mayuzumi, Berio
}

\section{Postwar Music History and the "Cultural Cold War"}

The relevance of the Cold War for the music history of the decades after 1945, which serves as a master narrative for Richard Taruskin, remains controversial. ${ }^{320}$ First, it is certainly obvious that the lasting influence of (cultural) politics on music in Soviet-dependent countries on the one hand, and those under the influence of the United States on the other hand, can hardly be doubted. Second, there is no denying that the music-semantic complexity of the music of composers like Igor Stravinsky, Pierre Boulez, Dmitri Shostakovich, or Hanns Eisler cannot be grasped with reference to contemporary or political discourses alone - and this claim can be made without having to assume an "aseptic" sphere of aesthetic difference divorced from the sociopolitical. Certainly, Taruskin is right to say unequivocally that there is no such thing as "apolitical music"321 and, in particular, that there is a connection between the aesthetics of serial music in postwar Western Europe and the Cold War mentalities of the same period (often considered "apolitical" in the past - or conversely decidedly political). ${ }^{322}$ In addition, Anne C. Shreffler has shown clearly that addressing the issues of control and freedom in the discussion of serial and aleatoric music cannot be understood as detached from the political ideologies of the time, in which these issues arose from battles between ideological camps. ${ }^{323}$

Ultimately, we must develop a perspective that can do justice to the complex relationships between music and society in the postwar era. In this respect, Martin Zenck suggests that Taruskin puts forward a "rather blunt equation of 'Cold War' and the strict and stringent organization of serial music, which is referred to as 'cold,' constructed and inhumane." ${ }^{324}$ Zenck rightly criticizes Taruskin's simplifying and distorting equation of the polemical aesthetic writings of René Leibowitz with Goebbels's propaganda and of Boulez's rhetoric with the "Communist journalism of his day," as well as the diagnosis of alleged "Nazi resonances" in Herbert Eimert's writings. ${ }^{325}$ There is no question, however, that an authoritarian rhetoric that spoke of the "worthlessness" of contrary aesthetic attitudes, or the "eradication" or "extinction" of certain residues of past styles, is found everywhere in the writings of the 1950 s and 60 .

Artists were sometimes well aware of the historical burden of such rhetoric. In this situation, in the early 1950s, a young composer like Pierre Boulez tried to write music that was emphatically based on historical experience and knowledge, a music

which distances itself from the abuse of the body and its sensations in Nazi ideology and its relative, the Vichy regime in France, a music [...] that cannot be used for any political machinations.

320 See in summary, among others, Schmelz, "Introduction: Music in the Cold War" and Shreffler, "Cold War Dissonance." In German-language musicology, the Cold War has so far been addressed largely in reviews of East German music history after 1945/48; see Jungmann, Kalter Krieg in der Musik and Tischer, "Musik in der Ara des kalten Krieges."

321 See Taruskin, "Afterword: Nicht blutbefleckt?," 276-277.

322 Shreffler, "Cold War Dissonance," 54-56.

323 See Shreffler, "Ideologies of Serialism," 221-225.

324 Zenck, Pierre Boulez, 64 ("ziemlich plumpe[] Gleichsetzung von 'Kaltem Krieg' [...] und der strikten wie stringenten Organisation der seriellen Musik [...], die als 'kalt', konstruiert und als [...] inhuman bezeichnet wird").

325 See Taruskin, Music in the Late Twentieth Century, 18. 
In this sense, it is an eminently political music that, in its internal organization and expression, follows the concept of a "committed literature" in the sense of Jean-Paul Sartre, without being explicitly or crudely connected to any external political content. ${ }^{326}$

And that the anti-communist cultural policy of the American occupying forces sometimes also promoted performances and institutions of the musical avant-garde $\mathrm{e}^{327}$ - in the sense of a defense of artistic freedom, more nolens volens than with real conviction - does not make the resulting works simply "products" of the Cold War. ${ }^{328}$

Finally, following the observations of Ben Parsons ${ }^{329}$ and Zenck, the "changeability of the temporal core as inscribed in the musical work, which unfolds in its post-history," ${ }^{330}$ must be taken into account. This aspect is reflected above all in the performance history ${ }^{331}$ and changing public reception of serial music and other avant-garde music during the 1950 s and 60 s. This history might arguably be interpreted as a fruitful public dispute and continued revision of positions, rather than ideological "blindness." 332

326 Zenck, Pierre Boulez, 66 ("[...] die sich vom Missbrauch des Körpers und seines Cefühls in der Nazi-Ideologie und dem mit ihr verwandten des Vichy-Systems in Frankreich distanziert, also eine Musik [...], die in keiner Weise politischen Machenschaften dienstbar gemacht werden kann. In diesem Sinne handelt es sich um eine eminent politische Musik, die von ihrer inneren Organisation und vom Ausdruck das Konzept einer 'engagierten Literatur' im Sinne Jean-Paul Sartres sucht, ohne mit einem externen politischen Außenhalt ausdrücklich und plakativ verbunden zu sein."). Of course, Sartre's position is exactly characterized by this "external political content," which Boulez declined. In addition, Sartre expressed in public discussion with René Leibowitz a stressed skepticism regarding the possibilities of a musique engagée. See also Carroll, Music and Ideology in Cold War Europe, 103-140 and Claser, "René Leibowitz und die Idee einer 'musique engagée."

327 The most thorough examination of this question can be found in Beal, New Music, New Allies. See also Beal, "Negotiating Cultural Allies" as well as Monod, Settling Scores. The share of funds of the US occupying power in the budget of the Darmstadt Summer Courses reached a maximum of about 20 percent only during three years (1949-51) (Beal, New Music, New Allies, 40). Skeptical positions on this question can also be found in Shreffler, "Cold War Dissonance," 58. Zenck states that "such support could never serve the political control of progressive composers such as Pierre Boulez, because they sought to realize their positions completely independently of political systems in order to finally escape the exploitation of music, as practiced previously by the Nazi ideology and the Vichy system." (Zenck, Pierre Boulez, 67 ["[...] dass entsprechende Unterstützungen nie der politischen Gängelung fortschrittlicher Komponisten wie Pierre Boulez dienen konnten, weil diese ihre Positionen vollkommen unabhängig von politischen Systemen zu verwirklichen suchten, um der Indienstnahme der Musik, wie sie durch die Nazi-Ideologie und die des Vichy-Systems zuvor gehandhabt wurde, endgültig zu entkommen."]). See also the nuanced treatment of these issues in Carrol, Music and Ideology in Cold War Europe, 91-102, Sprout, "The 1945 Stravinsky Debates," 120, and Wellens, Music on the Frontline, 121-126.

328 See Hiekel, "Angekommen im Hier und Jetzt?," 61.

329 Parsons, "Sets and the City."

330 Zenck, Pierre Boulez, 69-70 ("Veränderbarkeit des im jeweiligen Werk eingeschriebenen Zeitkerns, der sich in der Nachgeschichte entfaltet").

331 See Utz, "Zum performativem Hören serieller Musik."

332 Ofa "Cold War Blindness" Shreffler speaks in relation to the German-language music historiography of the $1970 \mathrm{~s}$ and 8os, especially in the work of Carl Dahlhaus: "One symptom of this 'blindness' was the implicit assumption that autonomous music was apolitical per se. The serial avant-garde was accordingly understood as the epitome of artistic autonomy. The fact that the political support for artistic autonomy was more covert than overt is one aspect of this 'blindness,' and in this sense inherent in the system. The efforts of Western governments to use cultural promotion as an instrument of international politics were largely unknown at the time, such as the support for the Darmstadt Summer Course by the US occupation or the activities of the CIA-sponsored Congress for Cultural Freedom (from which, among others, the journal Der Monat as well as the Berliner Festwochen 
Considering the historical situation after 1945, in which the entire continent of Europe was at the center of a global conflict between the new "superpowers," the United States and the Soviet Union, a tendency to view all manifestations of art or culture as having an implicitly global or international impact was particularly strong in Western Europe. The fact that the most influential trend in Western European postwar music, 1950s serialism, drew considerably on the idea of a "pure" (and therefore potentially "apolitical") structure is like the negative image of this all-encompassing public and political role often attributed to music and the arts in postwar societies. Indeed, the fact that music, and new music in particular, was part of this power struggle and was consciously conceived of as a medium or even "weapon" in the "Cultural Cold War" has been highlighted in a number of recent studies, ${ }^{333}$ though the extent to which this explicit political context shaped aesthetic and stylistic developments and decisions remains contested.

The dedicated attempts of influential institutions such as the Darmstadt Summer Course to avoid overt political topics or influences can clearly be seen as a counter-reaction to the politicized artistic doctrines of Soviet "socialist realism" reimplemented by Andrej Zhdanov in early 1948 and in the Prague Manifesto of the same year, adopted by the Second International Congress of Composers and Music Critics (20-29 May 1948), modifying but also affirming the Zhdanov doctrine $\left(\rightarrow\right.$ II.2). ${ }^{334}$ In both Western Europe and the United States, the sometimes naïve idealization of scientific thought - clearly exemplified by serial music theory - and the optimistic image and use of technology for experimental means were further indications of a close relationship between Western new music and capitalist modernism, eventually resulting in a re-academization of musical composition, most famously instigated by Milton Babbitt's efforts to install a $\mathrm{PhD}$ program in composition at Princeton University. ${ }^{335}$ And while technological progress had equally positive connotations in the Soviet-dominated sphere, the aesthetic appropriation of the social prestige attached to the sciences in art music during the postwar period was unique to the project of the Western avant-garde.

The general politicization in large parts of the musical world during the 1960 s and 1970s remained closely connected to world political events and developments, particularly in divided countries such as Germany ${ }^{336}$ and Korea. ${ }^{337}$ More generally, the tremendous effect of the Cold War in East Asia with the Maoist revolution in 1949, the withdrawal of the nationalist Chinese forces to Taiwan, the Korean War, and the division of Korea, suggests that from an Asian perspective, cultural or musical statements in this region were considered implicitly political, all the more since a concept of "musical autonomy" had not been established in Asian countries

emerged)." (Shreffler, "Dahlhaus und die 'höhere Kritik," 256 ["Ein Symptom dieser 'Blindheit' war die implizite Annahme, dass die autonome Musik per se unpolitisch sei. Die serielle Avantgarde wurde dementsprechend als Inbegriff der künstlerischen Autonomie verstanden. Dass die politische Unterstützung künstlerischer Autonomie eher im Verborgenen betrieben wurde, gehört mit zu dieser 'Blindheit' und ist insofern systemimmanent bedingt. So waren die Bestrebungen westlicher Regierungen, Kulturförderung als Instrument internationaler Politik einzusetzen, damals weitgehend unbekannt, wie zum Beispiel die Unterstützung der Darmstädter Ferienkurse durch die U.S.-Besatzung oder die Tätigkeiten des $\mathrm{CIA}$-geförderten Congress for Cultural Freedom (woraus unter anderem die Zeitschrift Der Monat sowie die Berliner Festwochen hervorgingen)."])

333 See Shreffler, "Ideologies of Serialism," 237.

334 Kovács, "Die Institution - Entstehung und Struktur," 118-119 and Carroll, Music and Ideology in Cold War Europe, 37-49.

335 Taruskin, Music in the Late Twentieth Century, 153-173.

336 See Noeske, Musikalische Dekonstruktion and Jungmann, Kalter Krieg in der Musik.

337 See Howard, Creating Korean Music and Killick, Hwang Byungki. 
on a broader basis before 1945. This does not mean that musical works in postwar East Asia were explicitly political in general; on the contrary, the majority of Western-oriented East Asian composers, like most of their Western colleagues well into the 1960s, tried to remain aloof from political engagement.

Although global politics was thus obviously a considerable factor of synchronization and interconnection in postwar music history, "Cold War ideologies" remain too crude and inflexible a framework for grasping the complex effects of musical works and performances on the diverse historical processes in different countries and regions of the world. Moreover, it seems inadequate and insensitive to the complexity of historical constellations and processes to place the aesthetic appropriation of scientific trends of the Cold War (even if they were based on or implied a certain authoritarian worldview) in (Western) serial music and the simultaneous control of composers and musicians in totalitarian regimes on the same level. In sum, "simultaneous" discourses or processes should not be simplified by attributing them to a common (in this case political-ideological) framework; rather, one must keep the "non-simultaneous" character of local music-related discourses in mind when trying to sketch the entanglements of global music-making in the postwar period. The following discussion will show that this is all the truer if one widens the perspective from the transatlantic situation to the global. For an appropriate music-historical account of the decades after 1945, nuance is required in order to avoid falling back into the polarizations that characterize this historical period.

\section{Henry Cowell, Toshirō Mayuzumi, Luciano Berio and the Tokyo 1961 East-West Music Encounter}

As demonstrated in Chapter II.2, both internationalism - as a form of composers', performers', and audiences' awareness of global interconnectedness and interdependence - and universalism - as the more or less open attempt to reach beyond the limitations of national or local musical confinements, guided by religious, technological, structural, or ethnic ideas and categories - may be understood as countermodels to the ubiquitous construction of composers as representatives of specific national or cultural identities by media, historians, and audiences. How, then, did the different facets of international and universal composition interact during the postwar period in such a way that simultaneous works and discourses reveal "non-simultaneous" preconditions and entangled histories? Three short case studies will address this question, focusing on the involvement of three prominent composers from different countries (United States, Japan, Italy) in a key event of the "Cultural Cold War."

The term "international" figured prominently in most activities and events hosted or supported by the Congress for Cultural Freedom (CCF), a CIA-sponsored organization that existed between 1950 and 1967 and played a crucial role in enhancing international relations in music and other arts during the 1950 s and 1960s, pursuing a decidedly anticommunist agenda. ${ }^{338}$

338 The secret financing of the CCF, founded in West Berlin in June 1950, by the CIA, which was mainly carried out through the shell organization Farfield Foundation, was disclosed in a series of articles in the New York Times in April 1966 and led initially to the renaming of the CCF as the International Association for Cultural Freedom (IACF), which was then funded by the Ford Foundation. In 1979, the organization dissolved. For basic information about the Congress for Cultural Freedom see among others Coleman, The Liberal Conspiracy, Hochgeschwender, Freiheit in der Offensive?, Stonor Saunders, The Cultural Cold War, Scott-Smith, The Politics of Apolitical Culture, and Wellens, Music on the Frontline. Musical institutions, works, and developments connected to the CCF are discussed, among others, in Stonor Saunders, The Cultural Cold War, Carroll, Music and Ideology in 
By funding large music festivals in Paris (1952), Rome (1954), Venice (1958), and Tokyo (1961), the CCF aimed to demonstrate the unlimited freedom of style and expression in contemporary music in the West as counterexample to the Soviet bloc's "controlled music" ("gegängelte Musik"). ${ }^{339}$ This is clearly documented in the introduction by the CCF's secretary general, the Russian-American composer Nicolas Nabokov, to the 1952 Paris festival:

During this coming arts festival, dedicated to l'CFuvre du XXe siècle, we will not hear any scores that do not owe their qualities, their very soul, to the fact that they are the music and the art of men who know the value of liberty. [...] And those who live today know this value of their times better because they have seen it. [...] If a music festival has a purpose and a virtue, it must be to combat hopelessness and discouragement. [...] Totalitarian ideologies [...] cannot diminish one inch the masterworks that speak for themselves - and for the civilization that gave them birth. ${ }^{340}$

A peak of the CCF's dedicated internationalism was the Tokyo East-West Music Encounter Festival and Conference in April 1961, co-funded by the Ford Foundation, purportedly aiming at closing the gap between the musical "East" and the musical "West." The festival and conference had been in planning since Nabokov's stay in Tokyo in 1955, but the realization had been delayed time and again due to political events and other factors. ${ }^{341}$ The CCF acted as the initiator and cofinancier, with funding mainly from the Rockefeller Foundation as well as the Japanese Society for International Cultural Exchange (KBK) and the Tokyo City Government. ${ }^{342}$ Both festival and conference attracted high-profile attendees from the United States, Europe, and East Asia (the conference program and a list of conference participants are provided in Table $2.2^{343}$ ). Elliott Carter, Colin McPhee, Lou Harrison, and Alan Hovhaness, among others, traveled from the USA alongside the 64-year-old Henry Cowell, while Luciano Berio, Iannis Xenakis, Bruno Maderna, and Boris Blacher, among others, came from Europe. Berio was in the process of moving his main residence from Italy to the United States, where he worked from 1962, initially at Mills College. In a concert on 5 May 1961 at the East-West Music Encounter Festival, Toshirō Mayuzumi's neoclassical orchestral work Bacchanale (1953) was performed under the direction of Seiji Ozawa by the New York Philharmonic; Cowell forwent the performance of his own work at the festival in Mayuzumi's favor (albeit not entirely voluntarily). ${ }^{344}$

Cold War Europe, Parsons, "Sets and the City," Shreffler, "Ideologies of Serialism," Beal, New Music, New Allies, Sheppard, "Continuity in Composing the American Cross-Cultural," and Giroud, Nicolas Nabokov.

339 Adorno's essay "Die gegängelte Musik" was written in 1948 in immediate response to Eisler's Prague Manifesto and was first published in 1953 in the Berlin journal Der Monat, which was supported by the CCF (other journals supported by the CCF included Encounter in London and Preuves in Paris) (Stonor Saunders, The Cultural Cold War, 26, 85-87, 138-158; see also footnote 332 above).

340 Nabokov, "Introduction à L'CEuvre du XXe siècle," 8, quoted in Parsons, "Sets and the City," 59.

341 Giroud, Nicolas Nabokov, 329. Initially the event had been scheduled for April 1959.

342 Ibid., 329-331.

343 The conference is discussed in Fukunaka, "Chinmoku suru 'seijin', chūshō ka sareta 'aika," Sheppard, "Continuity in Composing the American Cross-Cultural," 523-524, Borio, "Convergence Between West and East in 20th-Century Music," 109-110, Giroud, Nicolas Nabokov, 329-332, and Fukunaka, "World Music History and Interculturality."

344 Sachs, Henry Cowell, 473-474. 
Table 2.2: East West Music Encounter Conference, Tokyo 17-22 April 1961,

Program and List of Participants ${ }^{345}$

\section{Program (17-22 April 1961)}

17 April: Inaugural Session

18 April: The Difference in Musical Notions of the East and the West

The Eastern Musical Traditions

The Music of India

The Music of Indonesia

Music as a Liberal Art: Its Place in the Life of the Community

Religious Music (Liturgical and Religious Music)

Operatic and Ballet Music

Concert Music

19 April: Musical Interaction Between the East and the West

Western Studies of Eastern Music

Asian Music under the Impact of Western Culture

Problems of the Sino-Japanese Musical Tradition Today

Problems of the Indonesian Musical Tradition Today

Problems of the Indian Musical Tradition Today

Oriental Influence on Western Music

Western Music in the East

Western Music in Japan

Western Music in India

Western Music in the Philippines

The Composer in Japan Today

20 April: Music and the Listener. Panel Discussion;

Instruction in Music as Part of General Education

21 April: Expression and Technique in Contemporary Music:

Renewing the Musical Language

Extending the Classical Syntax

Electronic Composition

Stochastic Music

Refreshing the Auditory Perception

The Philosophy of Style

An Eastern View

Theme: Patronage of Music

Patronage of Music in the East

Patronage of Music in the West

Presenting the Eastern Tradition under Conditions of Mass Distribution

Situation of Creative Art in the Industrial Society

22 April: Critics' Forum 


\begin{tabular}{|l|l|}
\hline Conference Participants & \\
Arima, Daigoro & Moroi, Makoto \\
Arisaka, Yoshihiko & Murata, Takeo \\
Bekku, Sadao & Nomura, Koichi \\
Bhatia, Vanraj & Nomura, Yoshio \\
Carter, Elliott & Roy, R.L. \\
Cowell, Henry & Ruppel, Karl H. \\
Crossley-Holland, Peter & Sakka, Keisei \\
Cvetko, Dragotin & Schuh, Willi \\
Daniélou, Alain & Seefehlner, Egon \\
Draeger, Hans H. & Shiba, Sukehiro \\
Garfias, Robert & Singh, Thakur J. \\
Glock, William & Stuckenschmidt, Hans H. \\
Gostuški, Dragutin & Thomson, Virgil \\
Harewood, The Earl of & Toyama, Kazuyuki \\
Harrison, Lou & Tran Van Khe \\
Hirashima, Masao & Valenti-Ferro, Enzo \\
Hood, Mantle & Vatsyayan, Kapila \\
Kelemen, Milko & Viswanathan, T. \\
Kitazawa, Masakuni & Vlad, Roman \\
Maceda, José & Xenakis, lannis \\
McPhee, Colin & Yoshida, Hidekazu \\
Miyagi, Mamoru & Yuize, Shinichi \\
\hline selected festival participants not listed as conference speakers: \\
\hline Berio, Luciano & New York Philharmonic \\
Bernstein, Leonard & Japan Philharmonic Symphony Orchestra \\
Blacher, Boris & Gagaku Ensemble \\
Einem, Gottfried von & Gamelan-Ensemble (Bali) \\
Kontarsky, Aloys and Alfons & Royal Ballet (UK) \\
Maderna, Bruno & Royal Dancers of Thailand \\
Prey, Hermann & Kathakali Dance Group Kerala (India) \\
Stern, Isaac & \\
\hline
\end{tabular}

Though largely obscured by the propagation and endorsement of "freedom" in the arts, the hidden political motives of the CCF's activities, mainly its aim to "contain" leftist or more explicitly pro-Soviet tendencies, were obvious to many commentators and participants in Tokyo ${ }^{346}$ as well as at the earlier European events, although the CIA funding was revealed only in 1966. In addition, there was a general anti-American sentiment in Japan, with the previous year's ratification of the Ampo Pact (Treaty of Mutual Cooperation and Security between the United States and Japan, 19 June 1960), in which troop postings on Japanese territory were prolonged, provoking student protests.

Many of the composers participating in the Tokyo conference ostensibly shared Euroskeptic viewpoints, envisioning a new "universalist" musical idiom independent from dominating European trends such as serialism, while arguing for "preserving" non-Western traditions, sa-

346 Hayashi, "Two Opinions Over the Tokyo World Music Festival: II.” See Fukunaka, "Chinmoku suru ‘seijin', chūshō ka sareta 'aika."” 
ving them from the threat of a contaminating Western influence ${ }^{347}$ - not least in order to subject them to compositional appropriation. Cowell was particularly clear in this regard:

[...] composers would like to feel that they have the freedom to draw on worldwide musical resources, so we would like to do more of what Dr. Mantle Hood is doing in Los Angeles; that is in training groups of American people to play oriental instruments from all nations, to sing in oriental languages and styles and composers would like to draw on the tone quality of certain oriental instruments. We would like to include this and to have a worldwide and international field by drawing on the music which appeals to people all over the world. ${ }^{348}$

During the conference, ethnomusicologists and composers therefore unanimously demanded the preservation of "non-Western" traditional musical practices, which to them appeared under acute threat in the rapidly Westernizing Asian countries. ${ }^{349}$ This focus on the preservation of musical traditions did not occur "by coincidence," but was part of a larger trend in US foreign cultural policy at the time:

Especially at the time when the Vietnam War, civil rights movements, and revelations about covert $\mathrm{CIA}$ interventions in Africa, Asia and Latin America shattered faith in liberal universalism in favour of cultural relativism, [Ford Foundation] administrators considered investment in local heritages as a tactic of soothing those who criticised the American modernization programmes for being too one-sidedly focused on economic and political development at the expense of the indigenous traditions they sought to sustain. ${ }^{350}$

A memorandum written at the end of the conference outlined the project of an "International Institute for Comparative Music Studies." Two years later, in 1963, when Nabokov was invited by the Mayor of Berlin, Willy Brandt, to act as advisor to the city government on cultural matters, ${ }^{351}$ the Berlin International Institute of Comparative Music Studies and Documentation (iicmsd, in 1991 renamed International Institute for Traditional Music) was founded, financed through the Ford Foundation and directed by Alain Daniélou (the Institute was closed in 1996). ${ }^{352}$

Despite these connections, it would clearly miss the point to attribute the international or even universalist claims of both serial music and countertrends such as Henry Cowell's ethnically defined universalism exclusively to institutional and political history and denigrate these

347 See Cowell, "Oriental Influence on Western Music," Sheppard "Continuity in Composing the American CrossCultural," 523-524.

348 Henry Cowell in "Discussions. Music and the Listener," in: Executive Committee for 1961 Tokyo East-West Music Encounter, Music-East and West, 183-201: 197.

349 "Non-Western" within this conference denotes "Asian" exclusively, since African and Latin American music were conspicuously absent from the discussion.

350 Langenkamp, “(Dis)Connecting Cultures, Creating Dreamworlds," 221.

351 See Stonor Saunders, The Cultural Cold War, 295-296 and Ciroud, Nicolas Nabokov, 341-371.

352 "A Proposal by the Standing Committee of 1961 Tokyo East-West Music Encounter Conference," in: Executive Committee for 1961 Tokyo East-West Music Encounter, Music - East and West, 227-228. The Standing Committee included prominent names such as Yehudi Menuhin, Saburō Moroi, Alain Daniélou, and Hans H. Stuckenschmidt (see Giroud, Nicolas Nabokov, 332). The plan for such an institute went back to a meeting of Nabokov with Alain Daniélou in Madras in 1955 (ibid., 346) and was part of a comprehensive effort by the CCF to sustainably strengthen Berlin as the location of "free" culture, especially after the Berlin Wall had been built; the Berliner Festspiele also emerged from this process. See Stonor Saunders, The Cultural Cold War, 295-296. 
largely unpopular styles as corrupted by the ideologies of their day: "It is easy to dismiss the musical styles that we never liked anyway, if we can convince ourselves that they only existed as part of a CIA plot." ${ }^{353}$ However, such contexts reveal the important insight that "advanced music is not neutral (autonomous) or even necessarily critical, simply by virtue of its idiom. ${ }^{\text {"354 }}$ A closer look at three composers involved in the 1961 conference and festival will elaborate on this point, while hinting at their "non-synchronous" motives and presumptions: Henry Cowell (1897-1965), Toshirō Mayuzumi (1929-1997), and Luciano Berio (1925-2003) participated in (or can be at least associated with) the 1961 Tokyo Festival and Conference, with the sixty-four-year-old Cowell being promoted as a major figure by the American co-organizers. The personal participation of Mayuzumi in the conference at present cannot be confirmed, as he was on a six-month stay in the United States around that time, although, as mentioned above, a piece by him was performed during the festival. Far beyond the conference, the "entanglement" of all three composers with Cold-War-related institutions was significant for their careers and artistic development, despite their different ages, social status, and roles in their respective countries' musical scenes. Thus, their unlikely "encounter" at the Tokyo 1961 conference and festival provides an apt example of the "non-simultaneous" impact of simultaneous events in postwar music history.

\section{Henry Cowell and the Project of Hybridization}

Henry Cowell's compositional approach, aimed at hybridizing global musical traditions, was particularly conducive to the "cross-national" impulse of the East-West Music Encounter Conference. Cowell had been studying non-Western music cultures since the mid-1920s ( $\rightarrow$ II.4). His program of transethnic universalism developed in the early 1930s, and remained surprisingly consistent over more than three decades despite all the political changes during that period. Cowell increasingly regarded his approach as specifically American:

In my own music I believe I coordinate [...] musical means from all parts of the world, and from all ages of musical history. Into my inner creative needs I may feel the necessity of drawing on resources from any part of the world, folk or cultivated, and from any age, simple or complex. [...] In a way, I think of this as truly American, because America more than any other country, is made up of all the peoples of the world, and less than any other great composer-producing country does it have any one specific old tradition of musical composition. ${ }^{355}$

As shown in the previous chapter, Cowell systematically created works that deal with individual music cultures as well as culturally hybrid works. ${ }^{356} \mathrm{He}$ simultaneously tended toward a more conservative idiom contrasted with his early "ultramodernist" experiments, an idiom which was certainly better suited for representative political purposes than, for instance, John Cage's concurrent ascetic purism $\rightarrow$ II.6), despite the two composers' shared ideas and orientation toward universalism.

As early as the 1930s, Cowell had grown acquainted with Japanese music. Of particular importance was his encounter with the shakuhachi player Kitaro Tamada, who taught Cowell the

353 Shreffler, "Cold War Dissonance," 59.

354 lbid.

355 Cowell, statement Tokyo, 1 May 1961, quoted in Sheppard, "Continuity in Composing the American Cross-Cultural," 507.

356 See, among others, Nicholls, "Transethnicism and the American Experimental Tradition." 
instrument from 1937 during Cowell's imprisonment in San Quentin Prison (1936-40). ${ }^{357}$ In 1946, Cowell dedicated the solo work The Universal Flute for shakuhachi to Tamada. ${ }^{358}$ Crucial to the context of the Tokyo conference in 1961 was Cowell's year-long trip to Asia between August 1956 and September 1957, which was generously funded by the Rockefeller Foundation and the US Department of State. This trip took Cowell through Ireland, London, Turkey, Lebanon, Syria, Jordan, Egypt, Pakistan, India, Iran (for two months), Burma (Myanmar), Thailand, Indonesia, the Philippines, Hong Kong, Japan, and Korea. ${ }^{359}$ Comparable to the activities of the Congress for Cultural Freedom, the Rockefeller Foundation had been actively involved in the "Cultural Cold War" since 1955 and saw Asia as a key region, not least as a result of the Korean War. ${ }^{360}$

While still in Japan at the end of this journey, Cowell began composing the orchestral piece Ongaku in June 1957. The work, commissioned by the Louisville Orchestra, was inspired by the Japanese court music gagaku and the urban chamber music sankyoku. Cowell completed this work in September 1957 after his return to the US. ${ }^{361}$ Ongaku was directly influenced by the music Cowell heard during his stay in Tokyo; this included rehearsals by court musicians, gagaku court music, and shakuhachi music. Cowell was particularly impressed by the chord structures of the mouth organ shō in gagaku music $\left(\rightarrow\right.$ IV.). ${ }^{362}$

The work was a prelude to a series of works by Cowell inspired by Japanese instruments and musical genres, including two concertos for koto and orchestra. ${ }^{363}$ Cowell explicitly pursued an anti-European program, or, more specifically, a program directed against the contemporary serial avant-garde in Europe and the USA: "In 'drawing on resources' from nations such as Japan, Cowell's explicitly stated goal was to counter international serialism with a new musical universalism - on American terms." ${ }^{364}$ As part of the Tokyo conference, Cowell clarified that from his point of view, the interest in Asian music was primarily due to the diagnosis that Western music styles had already lost their "vitality" toward the end of the nineteenth century. ${ }^{365}$ Undoubtedly, Cowell's universalistic transethnicism benefited US diplomacy at the time:

His universalism and attempts to synthesize East and West in his music, however benign in motivation, worked hand-in-hand with U.S. Cold War efforts to form political bonds with Asian nations, particularly with Japan, much in the same way as state-sponsored radio broadcasts, lectures, and concerts of American music abroad [...]. [...] living "in the whole world of mu-

357 Sheppard, Continuity in Composing the American Cross-Cultural, 500-506. For a broader representation of the reception of Japanese traditional music in the twentieth-century USA see Sheppard, Extreme Exoticism.

358 Sheppard, Continuity in Composing the American Cross-Cultural, 505-506.

359 Sachs, Henry Cowell, 429-430. "For his 1957 tour, Cowell had been contacted by the U.S. Information Agency and asked to deliver lectures on contemporary American music with the explicit goal of promoting the image of the U.S. as a cultured nation to counter Soviet propaganda." (Sheppard, "Continuity in Composing the American Cross-Cultural," 507).

360 Sachs, Henry Cowell, 469-470.

361 Sheppard, "Continuity in Composing the American Cross-Cultural," 518.

362 Sachs, Henry Cowell, 453.

363 Concerto [no. 1] for koto and Orchestra (1962) and Concerto no. 2 for koto and Orchestra (1965). The Concerto for Harmonica (1962) was created at the same time and originally bore the title Haiku (Spirit of Japan), which was crossed out in the autograph (Sheppard, "Continuity in Composing the American Cross-Cultural," 518).

364 Ibid., 508.

365 Cowell, "Oriental Influence on Western Music," 72. 
sic" and subsuming all musics under an American label do involve a certain problematic egotism that resonates with U.S. covert imperialism of the past fifty years. ${ }^{366}$

Naturally one must treat such theses, which suggest a kind of "complicity" between artists and cultural politics or diplomacy, with a degree of caution. ${ }^{367}$ Even though the Head of the American Center in Japan, E.J. Findlay, thanked Cowell after a week-long lecture and concert tour in Japan after the East-West Music Encounter Festival "for all you did in Japan to win the cultural cold war," ${ }^{368}$ one must at least consider that Cowell's universalism was not an immediate result of the geopolitical situations of the Cold War, especially since it had developed from the $1920 \mathrm{~s}$ onwards. Certainly the Cold War provided additional motivation and encouragement for this perspective. Nevertheless, it is obvious that Cowell's approach, which, unlike John Cage's, gave up neither the concept of the work nor an essentialist concept of culture, was indeed suitable as a model for a diplomatic elite whose target group was a broad public.

How did Cowell's hybridized musical language actually materialize? In the introductory text to Ongaku, the composer wrote:

The foreign music strangest to Western ears is certainly that of the Far East: China, Korea and Japan. But the strangeness seems to be largely superficial: a matter of tone color and technique rather than structure. The basic relationship between music East and West is attested, I think, by the fact that Western orchestra performers will find nothing particularly surprising in their individual instrumental parts [in Ongaku] [...] in spite of the unfamiliar style in which the music is couched. [...] [the piece] is not an imitation of ]apanese music, but an integration of some of its usages with related aspects of Western music. [...] all the thematic material is my own; there are no actual Japanese themes in the work. The themes are extended by means of techniques for melodic variation that are common to both cultures. Western techniques for thematic development are not applied to the material. ${ }^{369}$

It is remarkable in this note that Cowell implicitly refers to his own work as "Japanese music" - from the perspective of American musicians and listeners - while emphasizing that he had not quoted any Japanese melodies. Autograph materials, meanwhile, have revealed a close connection between the first movement with the pitch structure and instrumentation of the tōgaku repertoire of gagaku Japanese court music. ${ }^{370}$ Cowell, however, chose the miyakobushi scale for the first movement. This scale had played a significant role in nationalist music theory and composition in the 1920 s to 40 s and had been conceptualized as specifically "Japanese" as described in Chapter II.4. It does not, however, appear in the togaku repertoire, but rather in certain koto and shamisen traditions of urban music during the Edo period (1600-1867) as in the pieces of sankyoku (trio setting originally of shamisen, koto, and the knee fiddle koky $\bar{u}$, increasingly replaced by the shakuhachi). In addition, Cowell's scale on the pitch G (G-Ab-(A)-C-

366 Sheppard, "Continuity in Composing the American Cross-Cultural," 507-508 and Sachs, Henry Cowell, $452-453$.

367 Cowell, like several other artists, was a consultant worker at the Office of War Information between the two world wars (OWI; United States War Information Office), where he was responsible for designing radio programs for US soldiers. See Cowell, "Shaping Music for Total War" and Beal, New Music, New Allies, 8-11.

368 Quoted in Sachs, Henry Cowell, 474.

369 Cowell, program note to Ongaku, quoted in Sheppard, "Continuity in Composing the American Cross-Cultural," 508 .

370 Sheppard, "Continuity in Composing the American Cross-Cultural," 510. 
$\mathrm{D}-\mathrm{E} b-\mathrm{G}$ ) includes the pitch $\mathrm{E} b$, which does not appear in the pitch system of tōgaku (Ex. 2.11). ${ }^{371}$ Likewise, the chords characterized by mild dissonances in high strings and woodwinds are not exact duplications or transpositions of the shö's aitake chords, which determine the harmony of togaku $\rightarrow$ IV.1). Thus, on the one hand, Cowell may have felt a special affinity for the "oriental" sounding miyakobushi due to his engagement with Persian and Arab music, while on the other hand, the references to Japanese traditions are possibly intentionally set in an imprecise manner in order to avoid the implication of "cultural imperialist" plagiarism. The combination of koto and gagaku traditions, which are strictly separated in the Japanese hogaku (traditional music) system, may also indicate a deliberate form of intra-Japanese hybridization, which is also suggested by the choice of the general title Ongaku ("Music" - in opposition to yōgaku, Western-oriented musical composition, and hōgaku, traditional Japanese music). ${ }^{372}$

Cowell was by no means the only composer fascinated by the musical traditions that Japan had institutionalized with great "success" since the Meiji restoration. Especially gagaku and the shō offered a point of attraction for many composers from both Japan and the West, including Iannis Xenakis, Olivier Messiaen, Benjamin Britten, Karlheinz Stockhausen, Tōru Takemitsu, Jean-Claude Eloy, and Toshio Hosokawa $(\rightarrow$ IV.). Except for the "scenic music" of Stockhausen with gagaku instruments from the late 1970s, ${ }^{373}$ the public in Japan responded favorably to these approaches of Western composers, as in Cowell's case. ${ }^{374}$ In all these cases, in the sense of

371 The modal system of gagaku has often been described in different ways and is characterized by some contradictions between theory and practice: "Gradually theory (even as rationalized in Japan) and evolving performance practice in gagaku diverged to a confusing degree" (McQueen Tokita and Hughes, "Context and Change in Japanese Music," 19). Fundamentally, one starts from a nine-note pitch repository, the pitches available on the mouth organ shō: $C-C \sharp-D-E-F \sharp-G-C \sharp-A-B b$ (i.e., without Eb, F , and B ) (Carfias, Music of a Thousand Autumns, 60). In the mode classes ryo (major third over the central tone) and ritsu (minor third over the central tone) categorized in today's practice, or three mode types on it (see ibid., 61-63), there are no formations that contain the typical miyakobushi trichord (C-Db-F). Although similar melodic formations sometimes occur in the context of the variable intonation of the leading reed hichiriki (see ibid., 133), Cowell, in the first movement of Ongaku, clearly uses the trichords C-Ab-C and G-Eb-D as a structural basis, not as intonational variants. Sheppard, in his account also referring to the compositional sketches, states that only the second movement of Ongaku was oriented to sankyoku, while the first movement was (exclusively) related to gagaku (Sheppard, "Continuity in Composing the American Cross-Cultural," 510). There is no doubt that the main models of both movements are unequivocal in terms of composition and instrumentation (in the second movement the gagaku model is retaken in measure 90 in a reminiscent form). It is, however, likely that Cowell, intentionally avoiding too close a reference to the original forms, consciously kept the modal system of the first movement "inauthentic," thus blending gagaku and sankyoku references in both movements.

372 This was also evident in the performance of the work in Japan: "some Japanese audience members were apparently disturbed by Cowell's juxtaposition of the sacred and ritualistic gagaku alongside the sankyoku genre of secular entertainment" (Sheppard, "Continuity in Composing the American Cross-Cultural," 511).

373 See Shimizu, "Stockhausen und Japan" and Utz, Neue Musik und Interkulturalität, 148-153. In the 1970s, Stockhausen developed the concept of "Szenische Musik," culminating in his music theater cycle Licht (1977-2003). Der Jahreslauf provides an early example of this approach. See Wirtz, Licht. Die szenische Musik von Karlheinz Stockhausen.

374 The koto soloist Kimio Eto (1924-2012), a student of the eminent koto reformer Michio Miyagi and soloist at the premiere of Cowell's first koto concerto, said of Cowell's Ongaku, "The degree of success with which Mr. Cowell has caught the flavor of Japanese music is illustrated by the reaction of a Japanese audience to [Ongaku] in 1959. It was enthusiastically received by older members of the audience. But some of the younger ones, whose musical leanings and experience are increasingly Western, were puzzled. 'Frankly, it's too Japanese for us,' said 
Example 2.11: Henry Cowell, Ongaku, first movement - pitch structures
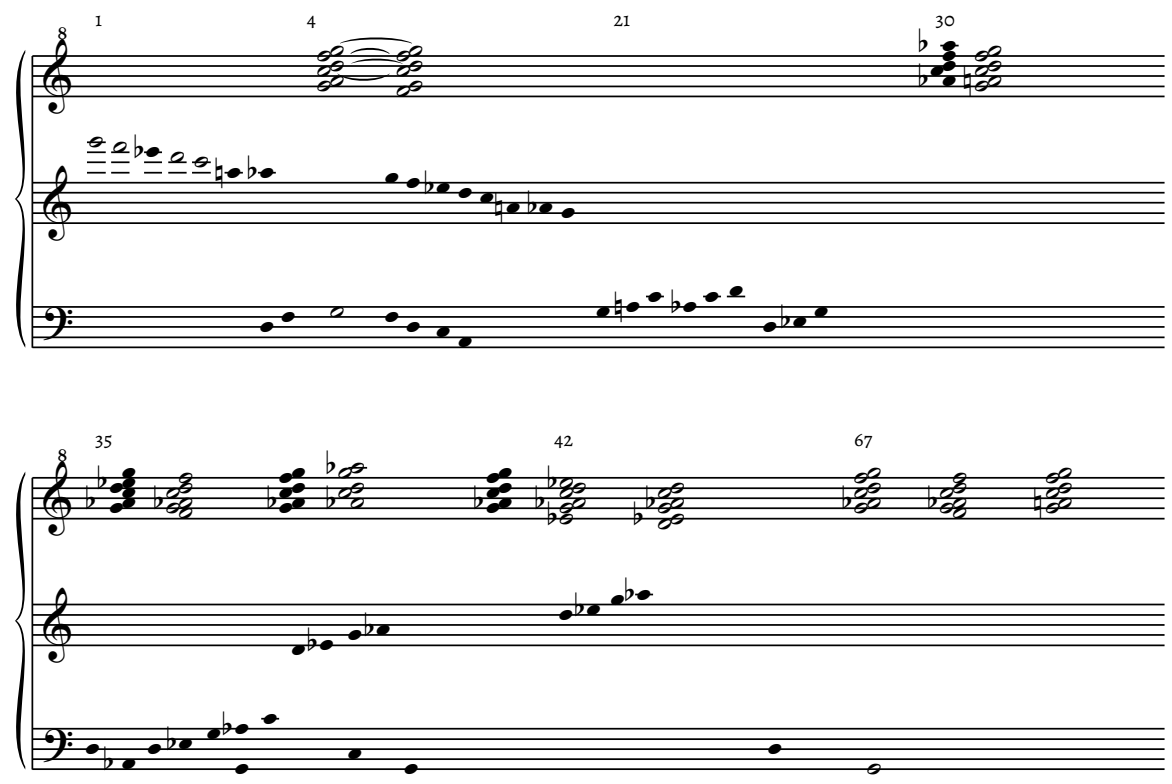

Andreas Meyer's "musical anthropology," 375 there is a tension between what is considered an "archaic," but in fact idealized, non-Western tradition (which, in the case of Japanese court music for example, was a construct of modern Japan) and the aesthetic demand after hybridizing such traditions under the conditions of musical modernity, where the forms of "synthesis" could by no means all be equivalent, but were subject to a controversial contemporaneous discourse.

\section{Toshirō Mayuzumi: Reception of Modernism and Neo-Nationalism}

In global music-political contexts, the polarization of "West" and "East" after 1945 made itself felt in a variety of ways, and also had a tremendous impact on postwar Japan. It may be too neutral to describe the development of Japanese music after 1945 as a "shared space" of European and Japanese musical culture (as Bonnie Wade does $^{376}$ ), as a common ground prepared by the systematic adaptation of European music since the Meiji restoration of 1868 . That such an adaptation had to be thoroughly reconceived after a period of fierce militarist aggression, war crimes, and the atomic catastrophe may be demonstrated by the example of Toshirō Mayuzumi, probably the most active and innovative Japanese composer during the 1950s. Mayuzumi presented a key work of a neo-national aesthetic in 1958 at the age of 29 with his Nirvana Symphony [Nehan kokyokyoku] for orchestra and male choir. The neo-national aesthetic, one that many artists in postwar Japan avoided or explicitly denounced, reminded many of the Japanese militarism in the Pacific War and its exploitation of traditional cultural symbols. Mayuzumi, born in 1929, was part of the composers' group San'nin no kai (Group of Three) founded

one, 'it's way over our heads." (Daniel Webster, "An Interview with Kimio Eto." Philadelphia Inquirer, 18/12/1964, quoted in Sheppard, "Continuity in Composing the American Cross-Cultural," 511).

375 See Meyer, "Volkstümlich - primitiv - populär." ( $\rightarrow$ II.1, II.2)

376 See Wade, Composing Japanese Musical Modernity, 39-95. 
in 1953, which also included Yasushi Akutagawa (1925-89) and Ikuma Dan (1924-2001). San'nin no kai was the only one of numerous groups to emerge during the 1950 s that attempted to connect to national or "pan-Asian" prewar trends. After a short period of study in Paris in 1951-52, Mayuzumi presented the earliest examples of musique concrète and electronic music in Japan, as well as orchestral and chamber works in different styles situated between neoclassicist and avant-garde idioms. ${ }^{377}$ Steven Nuss describes Mayuzumi's subsequent neo-nationalist turn as a "conscious decision in the late 1950 s and early 1960 s to reject or subjugate the considerable influence on him of contemporary Western (particularly French) compositional techniques and styles and to draw instead on his profound knowledge of Japan's traditional musical genres for musical inspiration" and thus as a "clear attempt to take what he saw as the West's insidious (musical) colonialism and flip it on its head."378

Mayuzumi tried to continue nationally-oriented prewar tendencies using new studio technologies: in a remarkable anticipation of spectral tendencies, he took spectral analyses of Japanese temple bells (bonshō), as the harmonic basis for moving "sound-masses" in movements 1, 3, and 5 (Campanology I-III) of the six-movement Nirvana Symphony. Characteristically, he wanted to make a trace of the "Japanese" in the bell spectrum via two pentatonic modes. ${ }^{379}$ The modes, however, are largely presented in a decidedly "modern," textural reading of the national element and integrated into a system of "verticalized" serial rows. ${ }^{380}$ The result is fundamentally different from Cowell's traditionalist hybrid style study designed just one year earlier. A modernity-driven critique of tradition is linked to a novel interpretation of the national element. The textural technique continues in some passages of movements 2,4 , and 6 (Śürangama; Mahāprajūāpāramitā; Finale). Here, the Buddhist recitation practices of various Japanese sects are taken up and dissolved into moving sound fields.

At the invitation of the Ford Foundation, Mayuzumi spent about six months in New York from the end of 1960, where he attended performances of his orchestral work Bacchanale (1953) by the New York Philharmonic under Leonard Bernstein at Carnegie Hall (13, 14, and 16 April 1961). He received a commission from the New York City Ballet and met with its director George Balanchine. Subsequently, he composed his two-movement orchestral work Bugaku (the score was completed on 23 March 1962 in Tokyo, and the world premiere was on 20 March 1963 in New York). ${ }^{381}$ Following on from his spectacular cello solo Bunraku (1960), Mayuzumi drew more and more explicitly on Japanese models - possibly also motivated by works such as Cowell's Ongaku, but maybe also by the Tokyo East-West Music Encounter Conference of $1961 .{ }^{382}$ In the context of

377 Galliano, Yōgaku, 166-168, 185-186.

378 Nuss, "Music from the Right," 86-87.

379 Mayuzumi, "Traditional Elements as a Creative Source for Composition."

380 Shimizu, "Mayuzumi Toshirō no kanpanoloji efekuto."

381 Mayuzumi, "Baranshin to barē 'Bugaku."

382 Other similarly oriented works by Mayuzumi from the same period include Sange (Scattering) for male choir (1959), the Mandala Symphony (1960), the symphonic poem Samsara (Reincarnation) (1962), and the cantata Ceka (Pratidesana) (Public Confession) (1963). "These compositions mirror his nationalist partiality through the use of Japanese elements and in some cases overtly nationalist messages" (Cook, "Venerable Traditions," 105). Yoritsune Matsudaira (1907-2001), 22 years older than Mayuzumi, had sought since the 1930s to integrate Japanese traditional material into Japanese new music, presenting an orchestral work of the same title, Bugaku, the previous year (1961). This work was awarded first prize at the competition of the annual festival of the International Society for Contemporary Music (ISCM) in Italy, and thus received widespread attention (Galliano, Yōgaku, 141). In contrast to Mayuzumi's increasingly explicit reference to Japanese models, Matsudaira tried to 
Example 2.12: Toshirō Mayuzumi, Bugaku, part 1, mm. 1-5 (vln. 2); the performance instruction written in the score reads: "Whole string should be played without vibrato through 11 . All glissandi marked - or w are to be played in such a manner that starting note is left immediately, producing an even gliding sound until the following note is reached. Melodies played by solo string players are to be played in such a manner that each note is stopped by a single finger (preferably on index finger of left hand) without changing the finger even if the note is changed."

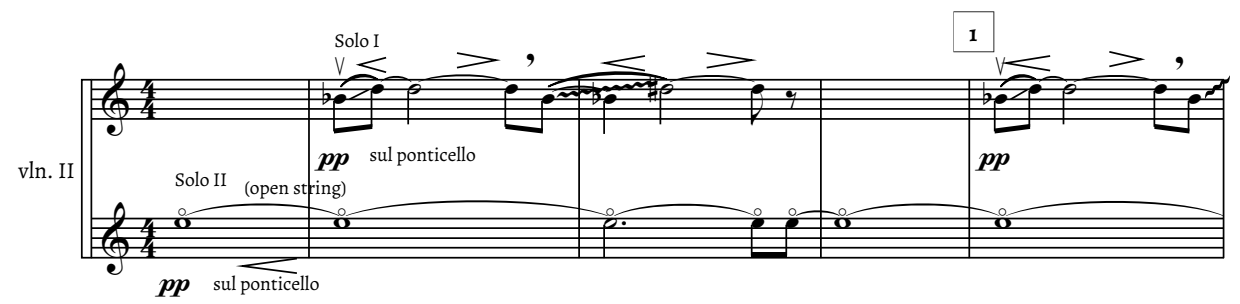

Copyright $\odot 1963$ by C. F. Peters Corporation, New York

the reference to the dance genre of the court music gagaku $u^{383}$ - a traditionalism characterized by the sliding notes of the beginning (Ex. 2.12) of the first movement transforming into a broad and affirmatively extended tutti - it seems clear how the tutti effect brutally overpowers the subtle study of the traditional style. In addition, it seems that besides a Western influence in the cyclic ostinato rhythms, we may also hear traits of gamelan structures, which had already provided a model for Mayuzumi since the early 1950 s. $^{384}$ In any case, the violent effect of the concluding tutti is symptomatic of Mayuzumi's neoconservative turn during this period, which - seemingly paradoxically - went hand in hand with a growing shift away from explicit references to the Japanese music tradition in the 1960s, although this process was not linear.

In Mayuzumi's works around 1960, one can retrospectively recognize an awareness of the need to strengthen the relevance of the national in order to counteract the questionable strategy of "catching up" with European developments, without - at that point - necessarily involving a "patriotic" or "narrow nationalist" outrage. ${ }^{385}$ Cultural essentialism, however, was thus foreshadowed as a central discourse that would strongly influence Japanese music at least until the 1980s, coinciding with a general increase in nationalist sentiments in Japanese society as mirrored in the nihonjinron (Japanese discourses). ${ }^{386}$

combine serial methods and tentative elements of aleatoricism, first used in Bugaku, with the Japanese pitch system.

383 In traditional bugaku, the "left dance" (sahō/samai; the dancer appears from the left side of the stage) is accompanied by tōgaku music in a solemnly sustained tempo, which can increase as the dance progresses, and is framed by two unmetered canonic sections (chōshi) (see Garfias, Music of a Thousand Autumns, 76-77), which corresponds to Mayuzumi's first movement. In the "right dance" (uhō/umai; the dancer appears from the right side), music from the komagaku tradition is played without any unmetered passages. The second movement of Mayzumi's work, which is characterized by ostinati, finally takes up the tutti material from the first movement to arrive at a "triumphant" finale. See Katayama, "Toshiro Mayuzumi," 21-22.

384 Galliano, Yōgaku, 185.

385 Cook, "Venerable Traditions," 125-126.

386 See Hijiya-Kirschnereit, Das Ende der Exotik. 
Mayuzumi's nationalism eventually became more politically explicit during the 1960s, conditioned by, among other factors, his encounter with the writer Yukio Mishima (1925-70), who had increasingly turned to nationalist ideas as a result of the protests against the Ampo Pact in 1960. As one of few Japanese composers, Mayuzumi combined the widespread cultural essentialism in the sense of minzoku shugi ("cultural tradition") with nationalist political ideology (kokumin shugi). ${ }^{387}$ Especially after Mishima's spectacular ritual suicide (following an "attempted coup") in 1970, Mayuzumi stepped up as a political activist and headed the nationalist organization Nihon wo mamoru kokumin kaigi (National Conference for the Defense of Japan; since 1997 Nippon kaigi, Japan Conference) from 1981-91. ${ }^{388}$ This group, which denied Japanese war crimes, set itself the goal of reviving the principles of the Japanese empire. During the same time, Mayuzumi's Showa tenpyōraku (1970) was the first work by a Japanese composer for traditional gagaku ensemble commissioned by the Tokyo National Theater, followed by many more. ${ }^{389}$

It is precarious to assert a direct connection between Mayuzumi's clearly positively accentuated reception of Western modernism and his political Japanese nationalism. It is as clear that both are closely related as it would be problematic simply to call Mayuzumi's highly virtuosic "synthesis" of European orchestral technique and substantial knowledge of Japanese pitch systems and practices "nationalist" - an approach that need not shy away from the comparison with Yoritsune Matsudaira or Tōru Takemitsu. Declaring Mayuzumi a musical nationalist tout court would ignore the tradition-critical impulse that found its way into Mayuzumi's scores along with his reception of modernity. It should also be considered that paradoxically, Mayuzumi, through the international context of the "Cultural Cold War," must generally have experienced support rather than obstruction for his neo-nationalist idiom, given that his specific combination of international postwar avant-garde and Japanese traditional idioms had resulted in a hybridity that coincided favorably with a politically motivated American cultural universalism. This was a universalism that Mayuzumi directly confronted during his stay in the USA (supported by the Ford Foundation) and at the 1961 Tokyo East-West Music Encounter.

\section{Luciano Berio: Collage Technique with "Suppressed Political Overtones"?}

The resistance to a culturally restrictive aesthetic approach in Europe, as represented especially by Karlheinz Stockhausen's works between 1958 and 1974 (not least triggered and reinforced by the composer's multiple trips to the United States and Japan, $\rightarrow$ II.2), was considerable from the beginning. This is reflected not least in the widespread lack of understanding among his fellow European composers (and in part audiences), who were presented in the early 1970s with the musical minimalism of Steve Reich or Terry Riley (which was also interculturally oriented). ${ }^{390}$ Less explored in this context is Luciano Berio's tendency toward transethnicism in the context of the musical collage technique for which his spectacular Sinfonia (1968, rev. 1969) has become famous. For these tendencies in Berio's work, the American influence must again be assigned a key role. Berio's acquaintance with John Cage, who had created Fontana Mix in Berio's Milanese RAI studio in 1958 and composed his Aria for Berio's American-born wife Cathy Berberian, was just one of the jigsaw pieces among Berio's many contacts with the United States. In her 2011 dissertation, Tiffany M. Kuo has compiled a precise chronology of Berio's US stays

387 See Cook, "Venerable Traditions," 100-101.

388 Havens, Radicals and Realists in the Japanese Nonverbal Arts, 258.

389 See Everett, "Mirrors of West and Mirrors of East," 182.

390 See Kleinrath, “Minimalismus/Minimal Music," 378. 
Example 2.13: Luciano Berio, Sinfonia, rehearsal number AA

Copyright $\odot 1972$ by Universal Edition (London) Ltd., London

and their (cultural-)political backgrounds. ${ }^{391}$ As early as 1952, Berio had been in the USA for the first time with the support of a Koussevitzky Foundation scholarship and participated in a composition course with Luigi Dallapiccola at the Berkshire Festival in Tanglewood, Massachusetts. From 1962 to 1974 Berio lived mainly in the USA, where he taught at the Juilliard School from 1965, among other activities such as numerous trips and concerts including a prolonged stay in Berlin from the end of 1964, funded by the Ford Foundation..$^{392}$

Berio's Folk Songs for mezzo-soprano and seven instruments from 1964 (arranged for mezzo-soprano and orchestra in 1973) can perhaps be seen as the composer's first approach to an emphatically multicultural concept that largely eschews any "structural" paradigm in favor of established "traditional" idioms. In the same period, Berio's experimental music theater works more strongly accentuated the political context of the time, in particular the "messa in scena" Passaggio (1961-62), based on texts by Edoardo Sanguineti, and Traces (1965) for two soloists, two actors, two choirs, and orchestra based on texts by Sanguineti and Susan Oyama, commissioned by the Koussevitzky Foundation (1961) and conceived for a premiere at the Library of Congress in 1965. The belated premiere in 1969 at the University of Iowa followed the rejection of the work by the head of the Music Division at the Library of Congress, Harold Spivacke. In response to the American Civil Rights Movement and President Lyndon B. Johnson's (1963-69) inaugural address (27 November 1963), with reference to J.F. Kennedy's testimony, which demanded that Americans "eliminate from this Nation every trace of discrimination and oppressions that is based upon race or color, ${ }^{393}$ Berio's work shows how traces of racial discrimination were still ubiquitous in everyday American life. ${ }^{394}$ Thus, Traces can be understood as a musical analogy to the critique of the reality of President Johnson's "Great Society" model that appeared in Herbert Marcuse's 1966 essay “The Individual in the Great Society."395 Berio's work was conceived exclusively for an African-American ensemble, with the exception of the mezzo-soprano, in which one of the opposing groups was to wear white masks. This confrontational dramaturgy was influenced by Jean Genet's play Les nègres (1957/58), which had become popular in the USA at the time through an off-Broadway production under the title The Blacks. ${ }^{396}$ In addition to the provocative libretto, this conception was found to be incompatible with the official line of "containment" and ultimately led to Spivacke's rejection. ${ }^{397}$ By contrast, Passaggio (which had caused massive public protests at the premiere in the Piccola Scala in Milan in May $1963^{398}$ ), a work committed to interaction and challenging the audience in the sense of Bertold Brecht's

391 Kuo, "Composing American Individualism."

392 Ibid., 13.

393 Quoted in ibid., 33.

394 The ratification of Kennedy's ]une 1963 Civil Rights Act, which banned racial discrimination and racial segregation, was delayed by Congress for almost a year and was not signed by Johnson until 2 July 1964.

395 Herbert Marcuse, "The Individual in the Great Society" [lecture at Syracuse University, 12/11/1965]. First published in Alternatives 1/1 (1966), 14-16/20 and 1/2 (1966), 29-35. See Kuo, "Composing American Individualism," 102-104.

396 See Kuo, "Composing American Individualism," 37-38.

397 Ibid., 36-39.

398 Ibid., 36; see also Ehrmann-Herfort, "Teatro per gli orecchi," 73-75. 
AA
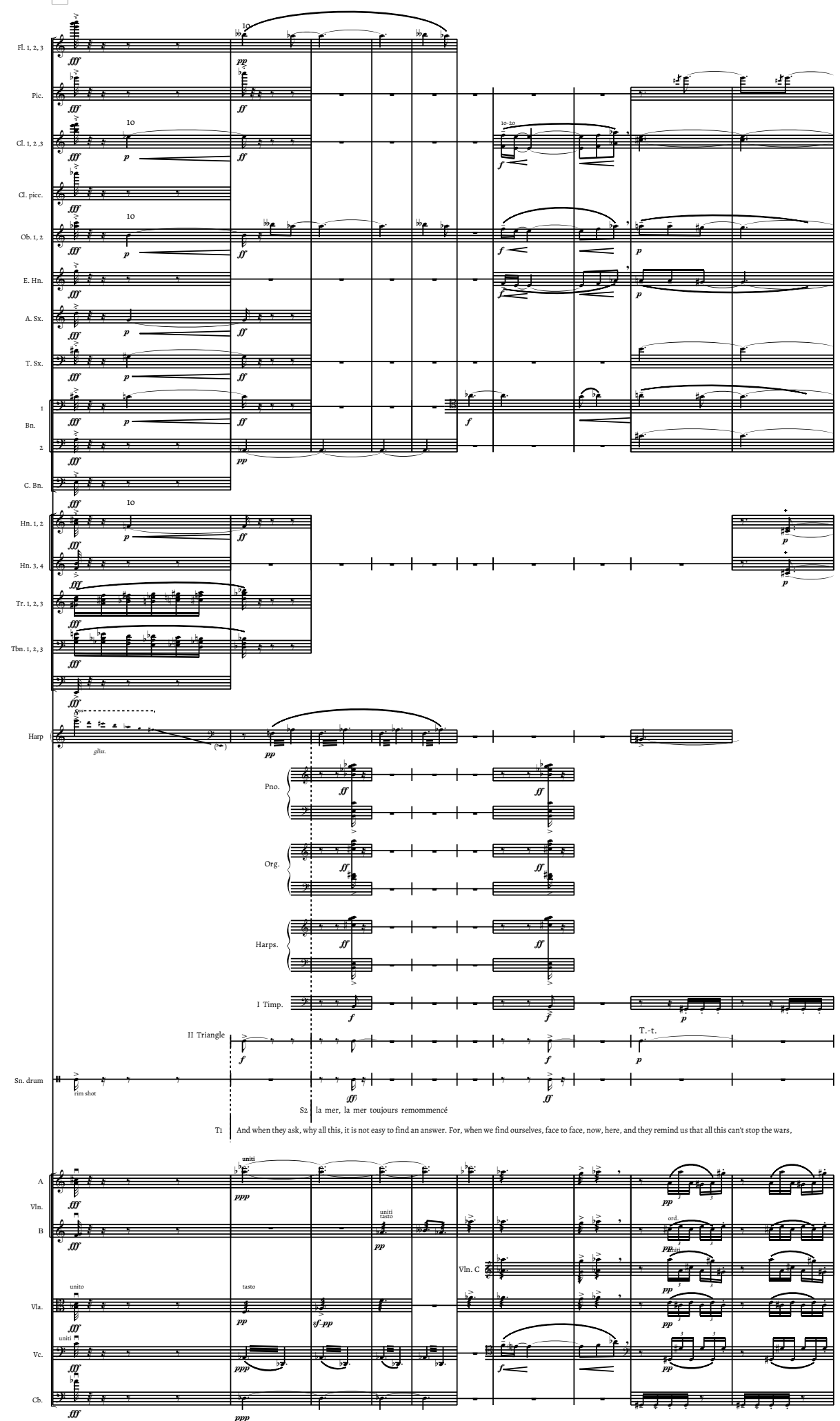
epic theater and Erwin Piscator's political theater, largely benefitted from a distinguished pub$\operatorname{lic}^{399}$ at the 1967 US premiere at the Juilliard School and Harvard University, supported by the Rockefeller Foundation. In this work, the problem of discrimination was treated in a more generalized social sense, ${ }^{400}$ less directly confronting contemporary US politics.

Later works by Berio such as Sinfonia and Coro (1975-76) reacted to these conflicting encounters with Realpolitik insofar as they radically expanded the plurality of cultural associations and stylistic levels already laid down in the two aforementioned music theater works into a comprehensive collage, ironically undermining overt political statements. In the third movement of Sinfonia, Berio paraphrases a sentence from a separate essay published in the same year (1968) - interrupting the flow of a textual layer from Samuel Beckett's The Unnamable - shortly after the recapitulation of Gustav Mahler's Scherzo from the Second Symphony, which serves as a structural basis for the movement (rehearsal number AA, Tenor I, Ex. 2.13): "[...] all this can't stop the war, can't make the old younger, or lower the price of bread"401 (in the essay, there was talk of "music" at this point, which is replaced by "all this" in the score, that is to say, it points self-referentially to the previously heard "music"402). The context and the simultaneous layers of additional musical and textual quotations here create a clear distance from any form of political activism: there are quotations from Debussy's La mer and Schoenberg's Orchestral Piece op. 16, no. 1, alongside a quotation (evoking the sea) from Paul Valéry's poem "La cimitière marin." The distancing from the political content of Berio's own statement is even more explicit in its second appearance in varied form - at the request "Say it again, louder!" (three measures after rehearsal number BB, Alto I); here the movement becomes involved in an "absurd" chain of associations, "desparate[ly]" spoken by Tenor I (five measures after rehearsal number BB):

it can't stop the wars, can't make the old younger or lower the price of bread, can't erase solitude or dull the tread outside the door, we can only nod, yes, it's true, but no need to remind, to point, for it is all with us, always, except, perhaps at certain moments, here among these rows of balconies, in a crowd or out of it, perhaps waiting to enter, watching. ${ }^{403}$

In addition, the two textual self-citations are separated by the intervening climactic chord ( $\mathrm{B}$ minor over the bass note $C$ ) from Mahler's Scherzo, abstracting the content of the spoken statements further as part of a formal music-speech dramaturgy.

In his article "Meditation on a Twelve-tone Horse," from the same year (1968), Berio adds to the sentence quoted in Sinfonia the idea that "[n]ever before [...] have responsible composers felt so compelled to challenge the meaning of and reasons for their work in relation to the world

399 Kuo, "Composing American Individualism," 106-109.

400 See Ehrmann-Herfort, "Teatro per gli orecchi," 73-75.

401 "And when they ask, why all this, it is not easy to find an answer. For, when we find ourselves, face to face, now, here, and they remind us that all this can't stop the wars, can't make the old younger or lower the price of bread" (Berio, Sinfonia, 87-88, rehearsal number AA). Foundational research on Berio' groundbreaking work is provided in Altmann, Sinfonia von Luciano Berio, Osmond-Smith, Playing on Words, and Bandur, "I prefer a wake," among others.

402 "We all know that music can't lower the cost of bread, is incapable of stopping (or starting, for that matter) wars, cannot eradicate slums and injustice." (Berio, "The Composer on His Work.") See Kuo, "Composing American Individualism," 135-137.

403 Berio, Sinfonia, 89-91. 


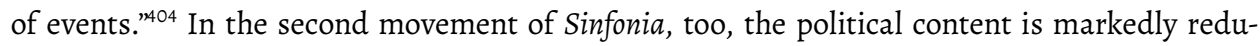
ced in comparison to the overtly political music of Traces: the textual material of this homage to Martin Luther King consists exclusively of the sounds of the name of the civil rights activist murdered during the composition of the work (4 April 1968; the second movement had already been composed in 1967). On this basis, Kuo diagnosed in Sinfonia "suppressed political overtones that would jeopardize a harmonious image of American freedom and democracy. [...] I argue that Berio acceded to George Kennan's 1965 exhortation to artists to 'forbear' rather than to criticize directly America's failings. ${ }^{405}$ The historian and diplomat George F. Kennan, the inventor of containment policy, in a White House speech in 1965 called for such "tolerance" of American artists toward the government, in exchange for the unlimited freedom that he afforded them at the same time - in deliberate contrast to the concept of "art as a weapon," which was attributed to Soviet cultural policy. ${ }^{406}$ The concept of freedom underlying this attitude was emphasized several times by the generally art-friendly administration of the Johnson presidency. On the one hand, freedom was understood as a "negative" freedom from restrictions (freedom of speech, religion, and assembly), but on the other hand as a "positive" freedom for the responsibility of the artist in society, with the goal of peace and "strengthening the nation," as formulated by president Johnson in $1965 .{ }^{407}$ Kuo makes it clear how this specifically American concept of freedom, as represented by the Congress for Cultural Freedom, found paradigmatic expression in Berio's Sinfonia: the work individualizes the listening experience of each recipient, especially since the strategies of perception in relation to the complexity of this text-music collage are heavily dependent on listening background, level of education, age, political attitude, etc. ${ }^{408}$ In this respect, the work realizes a maximum of "negative" freedom on the reception level. By contrast, examining Sinfonia and the evidence of past and present listeners' reactions to the work ${ }^{409}$ make the relationship between the art world and reality particularly explicit - albeit with almost no direct reference to daily politics - thus also honoring the aim of "positive" freedom.

Was Berio really a "model composer for America's cultural Cold War battle," as Kuo put it? Does the following conclusion not fall short? - "As an Italian-born American resident who garnered financial resources in academia, from private foundations, and from performing arts organizations, Berio reciprocated his gratitude with a sanitized and apolitical text in the second movement of Sinfonia to prove his allegiance. ${ }^{, 410}$ Berio undoubtedly showed a considerable understanding of the precarious political situation in his adopted American home, and Sinfonia (for example, via the involvement of the Swingle Singers, long known in popular culture before the world premiere of Berio's work) may even be something like a "designed success" (Morton Subotnick ${ }^{411}$ ). Even so, we can clearly see that Sinfonia is by no means the result of a politically corrupted aesthetic, but draws on the achievements of serial music - the autonomy of the individual in the context of a still-related whole, as well as the treatment of the various text sources - in the tradition of the late 1950 s and 1960s Sprachkomposition - the emancipation

404 Berio, "The Composer on His Work." See Kuo, "Composing American Individualism," 137.

405 Kuo, "Composing American Individualism," 31.

406 George F. Kennan, "The Arts and American Society," White House Speech 15/6/1965, quoted in Kuo, "Composing American Individualism," 150-151.

407 Quoted in Kuo, “Composing American Individualism," 183-184.

408 Ibid., 169-180.

409 See ibid., 158-169.

410 Ibid.

411 Quoted in ibid., 163. 
of the sound of language from the context of meaning. Therefore, the work participates in an essential development in compositional history. It was not until Coro - that is, after his return to Europe - that Berio resorted to an explicitly intercultural concept (music from Peru, Central Africa, and medieval and Romantic Europe are all incorporated into a pronounced structuralism $^{412}$ ), pursuing the aim to find "relations between very distant points. ${ }^{, 413}$ Still, a comparable universalistic model in the sense of a concert music "world theater" had already been developed in a mature form in Sinfonia. That Berio in these works avoided unambiguous political statements - as Bernd Alois Zimmerman does at the same time in his Requiem für einen jungen Dichter (1967-69), which is comparatively nuanced in its political message ${ }^{414}$ - without giving up the connection to the present, should be considered a particular quality. The cultural and political present in this work is tangible for every listener and signifies a quality that cannot be adequately interpreted according to any model based on the polarizations of the Cold War, no matter how much these were undoubtedly involved in Berio's concept.

In sum, the three case studies discussed in this chapter offer important historical insights: during the 1950s and 1960s, many composers consciously conceived of composing in a global political context; this awareness of "international" relations provided fertile ground for universalist concepts, even if they sometimes appeared in a "neo-nationalist" guise, as in Mayuzumi's case. However, Cowell's Ongaku, Mayuzumi's Bugaku, and Berio's Sinfonia respond to this situation with strikingly different and individual approaches that cannot be subsumed under any shared historical label. Cowell's American model of a "hybrid music," an idealized model of transethnicism; Mayuzumi's Japanese neo-nationalism, optimizing traditionalist structures by Western means; and Berio's politically abstracted form of universalist montage, to which we might add Stockhausen's emphatic "world music" ideas ( $\rightarrow$ II.2), occurred "simultaneously" on the historical stage but testify to radically different local, individual, political, and aesthetic preconditions of compositional craftsmanship, structural and timbral organization, performance, and reception. At the same time, all three composers were inclined to understand their music as particularly "public," linking their compositions to many of the other works mentioned earlier in this chapter, to which one might add idiosyncratic pieces like Luigi Nono's Intolleranza 1960 (1960), Tōru Takemitsu's November Steps (1967), Bernd Alois Zimmermann's Requiem für einen jungen Dichter (1967-69), or Alfred Schnittke's First Symphony (1972). Despite the evident political impact of all these works, it seems a clear underestimation of their semiotic ambiguity to reduce them to mere (if partly unconscious) reactions to (or results of) political discourses. By continuously reframing and reconsidering established concepts of identity, all these composers ultimately contributed to challenging the global hegemony of established Western concepts of music. Despite the various non-synchronous processes involved in the political and musical layers of their musical aesthetics, the anti-traditionalist impulse of

412 On the reference in Berio's Coro to the music of the Central African Banda Linda in Simha Arom's transcription, see Scherzinger, "Luciano Berio's Coro" and Dreyer, "Theorie aus der Ferne," 53-56. In Sequenza XIV for Violoncello (2002) Berio worked with information from the soloist at the premiere, Rohan de Saram, about traditional rhythmic models from Sri Lanka (de Saram's native country).

413 Berio, Two Interviews, 23.

414 For a comprehensive interpretation of this major work see Hiekel, Bernd Alois Zimmermanns Requiem für einen jungen Dichter. 
the Western postwar avant-garde and its paradoxical allegiance to so-called "traditional" musics reveal a basic ambiguity in postwar music history that, in its best moments, provided impressive proof of a general public relevance of art music. Considering the worldwide marginalization of art music's role in later periods and in today's commercialized and digitalized societies, one cannot help but see this public impact as the primary quality that distinguishes the globalized music of the postwar decades from that of the present.

\section{Categories of Intercultural Reception in Western Composition}

This concluding chapter of part II attempts to draw a broader picture of intercultural composition in the West than the admittedly narrow focuses of the three preceding chapters. The intention here is to follow the development of basic aesthetic and technical paradigms from the immediate postwar period to the more recent decades of the late twentieth and early twentyfirst centuries. Although "transnational" perspectives certainly predominate in the following, the exclusive attention given to Western composers may appear at odds with the "entangled" perspectives developed in the preceding chapters. Of course, we must acknowledge that many compositional processes, decisions, and innovations since the postwar period were and are still deeply dependent on specific processes that Western music history has created. The impact of John Cage, explored at the beginning of this chapter, is surely a case in point. Also, as the final part of this chapter on compositions for the Chinese mouth organ sheng demonstrates, the migration of performers and composers tends to make a neat definition of the "West" increasingly arbitrary from the final period of the twentieth century onward - even though cultural essentialism (as we will see) was doubtless still relevant and influential for musical thought and compositional agency.

The self-referentiality of postwar serial "logic" and John Cage's conception of a music "free of likes and dislikes" shared a suppression of ethnic layers: it is no coincidence that Cage's transfer of the model of "unimpededness and interpenetration" (wu ai yuan rong), derived from Huayan Buddhism, to an intentionless continuum of sounds and silences ${ }^{415}$ emerged in close dialogue with Pierre Boulez's early serial techniques. ${ }^{416}$ Both concepts can be equally understood as attempts to free music from any form of established grammar or idiom. Postserial Sprachkomposition of the late 1950 s and $1960 \mathrm{~s}^{417}$ whose tradition is still alive today, continued to flirt with a rigorous elimination of semantic components of language(s), as in György Ligeti's Aventures (1962), which (like Mauricio Kagel's Anagrama, 1957-58) was based on a meticulously organized system of asemantic sounds free from the rules of existing languages. At the same time, Sprachkomposition instigated a dynamics compensating for such a negation of language: Dieter Schnebel's Glossolalie 61 (1961-65), distinguished by the inclusion of an abundance of language and articulation systems, and Karlheinz Stockhausen's universalism of the 1960s, which culminated in the controversial electronic works Telemusik (1966) and Hymnen (1965-67) $(\rightarrow$ II.2), can be perceived as globally expanded attempts to recapture the ability of music to "speak" in different idioms and

415 See Pritchett, The Music of John Cage, 74-78, Klein, "Cegenseitige Durchdringung und Nicht-Behinderung," and Utz, Neue Musik und Interkulturalität, 78-84.

416 See Nattiez and Piencikowski, Pierre Boulez-John Cage. Correspondance et documents.

417 See Klüppelholz, Sprache als Musik for an introduction into the key works of German Sprachkomposition, and Utz and Lau, Vocal Music and Contemporary Identities for a broader few on intercultural tendencies in twentiethcentury vocal music. 